\title{
Canopy Position and Heat Treatments Influence Gamma-irradiation-induced Changes in Phenylpropanoid Metabolism in Grapefruit
}

\author{
R.E. McDonald, W.R. Miller, and T.G. McCollum \\ U.S.Department of Agriculture, Agricultural Research Service, U.S. Horticultural Research Laboratory, \\ 2001 South Rock Road, Fort Pierce, FL 34945 \\ AdDitional Index words. Citrus paradisi, postharvest quality, vapor heat, pitting, PAL activity, phenolic compounds, sterols
}

\begin{abstract}
Irradiation is being evaluated as a quarantine treatment of grapefruit (Citrus paradisi Macf. 'Marsh'), but it can cause damage to the fruit. Research was conducted to determine if preirradiation heat treatments would improve fruit tolerance to irradiation as they improve tolerance to low temperature injury and to determine if canopy position influenced fruit tolerance to irradiation. Initially, grapefruit were irradiated at 0 or $2.0 \mathrm{kGy}$ at a dose rate of $0.14 \mathrm{kGy} \cdot \mathrm{min}^{-1} \mathrm{and} \mathrm{selected}$ biochemical changes were monitored over time. There was a marked increase in phenylalanine ammonia-lyase (PAL) activity following irradiation. Maximum activity ( $\approx 18$-fold increase) was attained 24 hours after irradiation. Subsequently, grapefruit were harvested from interior and exterior canopy positions and irradiated at 0 or $1.0 \mathrm{kGy}$ at a dose rate of $0.15 \mathrm{kGy} \cdot \mathrm{min}^{-1}$ before storage for 4 weeks at $10{ }^{\circ} \mathrm{C}$. Following storage, pitting of flavedo was the most evident condition defect noted as a result of irradiation. Pitting was observed on $27 \%$ and $15 \%$ of irradiated exterior and interior canopy fruit, respectively, whereas there was no pitting on nonirradiated fruit. Heat treatment before irradiation decreased susceptibility of fruit to damage. Pitting was $26 \%, 19 \%$, and $17 \%$ when fruit were held 2 hours at 20 (ambient), 38 or $42{ }^{\circ} \mathrm{C}$, respectively. Irradiation-induced PAL activity was reduced by temperature conditioning at 38 or $42{ }^{\circ} \mathrm{C}$. Exterior canopy fruit flavedo contained higher levels of total phenols, including flavanols and coumarins compared with interior canopy fruit. Deposition of lignin was not related to canopy position. Neither irradiation nor heat treatment had an effect on total phenols or lignin deposition. Generally, cholesterol, campesterol, stigmasterol, $\beta$-sitosterol, and isofucosterol were found to be higher in four steryl lipid fractions in exterior canopy fruit compared with interior canopy fruit. Irradiation increased campesterol in the free sterol and steryl glycoside fractions and decreased isofucosterol in the free sterol fraction. Heat treatments had no effect on individual sterol levels. It seems that irradiation causes a stress condition in the fruit, which leads to pitting of peel tissue. Heat treatment before irradiation reduced damaging effects of irradiation.
\end{abstract}

Irradiation, an alternative to methyl bromide fumigation for nine Tephritid fruit flies species, is expected to be approved by the Animal and Plant Health Inspection Service (APHIS) of the U.S. Department of Agriculture (USDA) in the near future (U.S. Government Printing Office, 1996). A minimum absorbed dose of $0.15 \mathrm{kGy}$ has been proposed to sterilize the Caribbean fruit fly (Anastrepha suspensa Loew) (CFF) (USDA, 1996). Grapefruit (Citrus paradisi) exported from Florida to certain overseas markets and other citrus producing states must be certified free of living CFF larva before shipment. Currently, most grapefruit destined for markets requiring quarantine security against the $\mathrm{CFF}$ are produced in certified CFF-free zones under the Standard Season CFF Protocol (Simpson, 1993). However, future outbreaks of pest infestation could render current CFF-free zones noncertifiable and make the use of alternative quarantine methods necessary.

Irradiation is a potential quarantine treatment of grapefruit against the CFF (von Windeguth, 1982). However, grapefruit are only moderately tolerant to irradiation. Slight peel damage may develop on Florida grapefruit at absorbed dosages of 0.15 to 0.3 kGy (Hatton et al., 1984; Miller and McDonald, 1996). Florida citrus marketing standards for U.S. Fancy or U.S. Grade No. 1

Received for publication 18 Aug. 1999. Accepted for publication 4 Jan. 2000. We thank Roxanne Wiseman and Lisa Santiago for competent technical assistance during the course of this work. Mention of a trademark, warranty, proprietary product, or vendor does not constitute a guarantee by the U.S. Dept. of Agr. and does not imply its approval to the exclusion of other products or vendors that may also be suitable. The cost of publishing this paper was defrayed in part by the payment of page charges. Under postal regulations, this paper therefore must be hereby marked advertisement solely to indicate this fact. grapefruit do not allow for any peel injury (USDA, 1968). Because of the large volumes of grapefruit that will be shipped at any one time, it will probably be necessary to irradiate entire pallet units. Irradiation of grapefruit in cartons stacked in pallet units necessarily exposes some fruit in the outermost cartons to higher doses than the minimum required dose of $0.15 \mathrm{kGy}$ for fruit located in the innermost cartons. The maximum-minimum dose ratio will probably be $\approx 2.67: 1$ for pallet units of grapefruit, based on previous dosimetry observations on a papaya (Carica papaya L.) pallet unit by the authors (unpublished data). Hence, some fruit could be exposed to $\geq 0.4 \mathrm{kGy}$ to obtain the minimum 0.15 $\mathrm{kGy}$ absorbed dose. Increasing the tolerance of grapefruit to low dosage irradiation would provide a margin of safety against peel damage and make irradiation a more feasible alternative to currently used quarantine treatments.

Peel pitting of grapefruit caused by low-dose irradiation develops $\approx 7 \mathrm{~d}$ after treatment and is expressed as relatively small circular necrotic lesions on the peels. Symptoms of irradiationinduced pitting of grapefruit are similar to chilling injury (CI) caused by low temperatures (Hatton and Cubbedge, 1983). Heat treatments have increased chilling tolerance in several chillingsensitive tissues including grapefruit (Klein and Lurie, 1992; Paull and McDonald, 1994). In addition, the location of grapefruit within the tree canopy (exterior or interior) can affect its sensitivity to low-temperature injury (McDonald et al., 1993; Purvis, 1980). Recently, Miller and McDonald (1998) found that a vapor heat treatment before exposure to low-dose irradiation reduces the incidence of peel injury $\approx 50 \%$, demonstrating that heat treatments will reduce more than one abiotic stress.

Physiological changes in fruit tissues after gamma irradiation 
have included induction of stress protein synthesis (Ferullo et al., 1994; Riov and Goren, 1970), losses in flavor and texture (Romani, 1966), and changes in lipid levels (Gholap et al., 1990; Lester and Whitaker, 1996). In turn, lipids contribute as precursors to aroma and flavor constituents of fruits (Buttery and Ling, 1993) and may play a role in determining fluidity and permeability of cellular membranes (Mudd and McManus, 1980). Accumulation of phenolic compounds and the activity of phenylalanine ammonialyase (PAL), the major enzyme involved in their synthesis, have been implicated in abiotic stresses of citrus fruit. PAL activity is induced by physical abrasion of the peel (Ismail and Brown, 1979), by exposure to ethylene (El-Kazzaz et al., 1983; Riov et al., 1969), and exposure to low temperature (Martinez-Tellez and Lafuente, 1997). Accumulation of phenolic compounds occurs in flavedo cells following irradiation (Lester and Wolfenbarger, 1990; Riov, 1975).

The present study was undertaken to determine if grapefruit canopy position affects sensitivity of grapefruit to gamma irradiation and if a short-term heat treatment before irradiation would reduce the severity and incidence of peel injury (pitting) resulting from irradiation stress. Changes in PAL activity, phenolic compounds, and steryl lipids were characterized over time following irradiation.

\section{Materials and Methods}

Plant material and treatments. All fruit in this study were 'Marsh' grapefruit, having a mean diameter of $8.9 \mathrm{~cm}$ (commercial size of 40 count), and harvested three times from a commercial grove near Fort Pierce, Fla., during February and March 1997. The first phase of the experiment followed selected biochemical changes over time in grapefruit flavedo induced by irradiation. Fruit were harvested from exterior canopy positions from 10 individual trees within a production block and transported to the U.S. Horticultural Research Laboratory (USHRL), Orlando, Fla. Ten fruit were packed in 14.1-L commercial citrus cartons and the following day were treated at 0 or $2.0 \mathrm{kGy}$ using ${ }^{60} \mathrm{Co}$ as a radiation source (FTS, Mulberry, Fla.) at a dose rate of $0.14 \mathrm{kGy} \cdot \mathrm{min}^{-1}$. A $2.0 \mathrm{kGy}$ dose was administered to ensure that irradiation-induced biochemical changes would occur. Three replicate flavedo samples were taken at $0,6,12,18,24,48,72$, or $96 \mathrm{~h}$. From each subsample of 10 fruit, $14 \mathrm{~g}$ were frozen in liquid $\mathrm{N}_{2}$ and held at $-10{ }^{\circ} \mathrm{C}$ for phenol, flavanol, lignin, and coumarin analyses. An additional $14 \mathrm{~g}$ were frozen in liquid $\mathrm{N}_{2}$, freezedried, and held at $-80{ }^{\circ} \mathrm{C}$ for PAL activity and lipid analysis.

The second phase of the experiment concerned the effects of grapefruit tree canopy position, heat treatments, and irradiation on peel pitting and biochemical changes in flavedo tissue. Fruit were harvested from 50 individual trees within a production block. On each harvest date, fruit were harvested from exterior (sun exposed) canopy positions and from interior (shaded) canopy positions. The fruit were taken to the USHRL and randomized into plastic bins by canopy position. Fruit from each canopy position were held at ambient $\left(20^{\circ} \mathrm{C}\right)$ or heat-treated at 38 or 42 ${ }^{\circ} \mathrm{C}$ by vapor heat for $2 \mathrm{~h}$ with an airflow of $0.4 \mathrm{~m}^{3} \cdot \mathrm{s}^{-1}$. After cooling to ambient conditions for $8 \mathrm{~h}$, fruit were washed on a commercialtype brush bed with soap (Sooty Mold Cleaner; EcoScience, Orlando, Fla.) and water, and waxed (590HG citrus wax; FMC Corp., Lakeland, Fla.). Following washing and waxing, 10 fruit from each treatment combination were placed in citrus cartons. Fruit that were to be used for chemical analysis were not washed and waxed. The following day, fruit were treated at 0 or $1.0 \mathrm{kGy}$ at a dose rate of $0.15 \mathrm{kGy} \cdot \mathrm{min}^{-1}$. Irradiation at $1.0 \mathrm{kGy}$ was chosen because it is the maximum level permitted by the U.S. Environmental Protection Agency to treat fresh fruits and vegetables. There were six boxes (subsamples) for each combination of canopy position (exterior/interior), temperature $(20,38$, or 42 ${ }^{\circ} \mathrm{C}$ ), and irradiation dose ( 0 or $1.0 \mathrm{kGy}$ ), for a total of 720 fruit per harvest (replication).

Following irradiation, fruit that had been washed and waxed were stored at $10^{\circ} \mathrm{C}$ and $90 \% \pm 5 \%$ relative humidity for 4 weeks plus 1 additional week at $20^{\circ} \mathrm{C}$ for condition defects. Fruit were rated for postharvest peel pitting, the most common type of irradiation damage (Miller and McDonald, 1998). Fruit that were not waxed were held for $24 \mathrm{~h}$ at $20^{\circ} \mathrm{C}$ and sampled by removing the flavedo layers with a potato peeler. Subsamples of 10 fruit were prepared as above.

Pal activity. A procedure similar to that described by Zucker (1968) was used to extract and assay PAL. Acetone powders were prepared from freeze-dried tissue. Protein was extracted by suspending $0.3 \mathrm{~g}$ powder in $25 \mathrm{~mL}$ cold $0.1 \mathrm{~mol} \cdot \mathrm{L}^{-1}$ borate buffer, $\mathrm{pH}$ 8.8. The suspensions were shaken at $1{ }^{\circ} \mathrm{C}$ for $1 \mathrm{~h}$, filtered through cheesecloth, and centrifuged at 25,000 $g_{\mathrm{n}}$. Supernatants were decanted and adjusted to $70 \%$ saturation by adding ammonium sulfate and shaken overnight at $1{ }^{\circ} \mathrm{C}$. After centrifuging at $25,000 g_{\mathrm{n}}$ for $20 \mathrm{~min}$, supernatants were decanted, precipitates were dissolved in $2 \mathrm{~mL} 0.1 \mathrm{~mol} \cdot \mathrm{L}^{-1}$ borate buffer, and dialyzed overnight at $1^{\circ} \mathrm{C}$ against distilled $\mathrm{H}_{2} \mathrm{O}$. Protein concentration was determined by using the Lowry method (Peterson, 1977). Reaction mixtures contained $700 \mathrm{~mL}$ extraction buffer, $200 \mathrm{~mL}$ sample extract, and $200 \mathrm{~mL} 0.1 \mathrm{~mol} \cdot \mathrm{L}^{-1} \mathrm{~L}$-phenylalanine (substrate). Reaction mixtures were incubated at $40^{\circ} \mathrm{C}$ for $5 \mathrm{~h}$ and then stopped by adding $100 \mathrm{~mL} 5 \mathrm{~mol} \cdot \mathrm{L}^{-1} \mathrm{HCl}$. The concentration of trans-cinnamic acid (product) was determined spectrophotometrically at $290 \mathrm{~nm}$.

Total Phenols AND Flavanols. A procedure similar to Swain and Hillis (1959) was used to extract and determine total phenols and flavanols. Previously frozen flavedo tissue $(1.0 \mathrm{~g})$ was homogenized in $10 \mathrm{~mL} 17.2 \mathrm{~mol} \cdot \mathrm{L}^{-1}$ methanol for $5 \mathrm{~min}$, diluted to $40 \mathrm{~mL}$, stirred for $1 \mathrm{~h}$ and filtered. Total phenols in the methanol extracts were measured by the Folin-Ciocalteu method and flavanols by vanillin reagent. To determine total phenols, the filtrates were diluted with distilled $\mathrm{H}_{2} \mathrm{O}, 2 \mathrm{~N}$ Folin-Ciocalteu reagent was added, and vortexed. After $1 \mathrm{~min}$, saturated sodium carbonate was added, the reaction mixture incubated for $2 \mathrm{~h}$ at ambient temperature, and absorbance at $725 \mathrm{~nm}$ measured. To determine total flavanols, the filtrates were placed into tubes containing $0.066 \mathrm{~mol} \cdot \mathrm{L}^{-1}$ vanillin reagent in $12.6 \mathrm{~mol} \cdot \mathrm{L}^{-1}$ sulfuric acid, vortexed, incubated at ambient for $15 \mathrm{~min}$, and absorbance at $500 \mathrm{~nm}$ measured.

Lignin (PHENOLIC POLYMERS) AND COUMARINS. A procedure similar to Graham and Graham (1991) was used to extract and determine lignins and the method of Dubery (1992) was used to extract and determine coumarins. Previously frozen flavedo tissue $(1.0 \mathrm{~g})$ was homogenized in $20 \mathrm{~mL}$ chloroform for $1 \mathrm{~min}$, filtered, and washed twice with $20 \mathrm{~mL} 2$ methanol : 1 chloroform : 8 water (by volume), and twice with $20 \mathrm{~mL}$ acetone. For lignin determination, a $10-\mathrm{mg}$ residue was then suspended in $500 \mathrm{~mL}$ $1.4 \mathrm{~mol} \cdot \mathrm{L}^{-1}$ thioglycolic acid in $2 \mathrm{~mol} \cdot \mathrm{L}^{-1} \mathrm{HCl}$ and transferred to a glass vial with a Teflon cap. The suspension was heated at 100 ${ }^{\circ} \mathrm{C}$ for $4 \mathrm{~h}$, cooled, transferred to a microfuge tube, and centrifuged at 18,000 $g_{\mathrm{n}}$ for $6 \mathrm{~min}$. The pellet was washed with $500 \mathrm{~mL}$ distilled $\mathrm{H}_{2} \mathrm{O}$ and recentrifuged. The washed pellet was then suspended in $500 \mathrm{~mL} 1 \mathrm{~mol} \cdot \mathrm{L}^{-1} \mathrm{NaOH}$ and vortexed repeatedly 


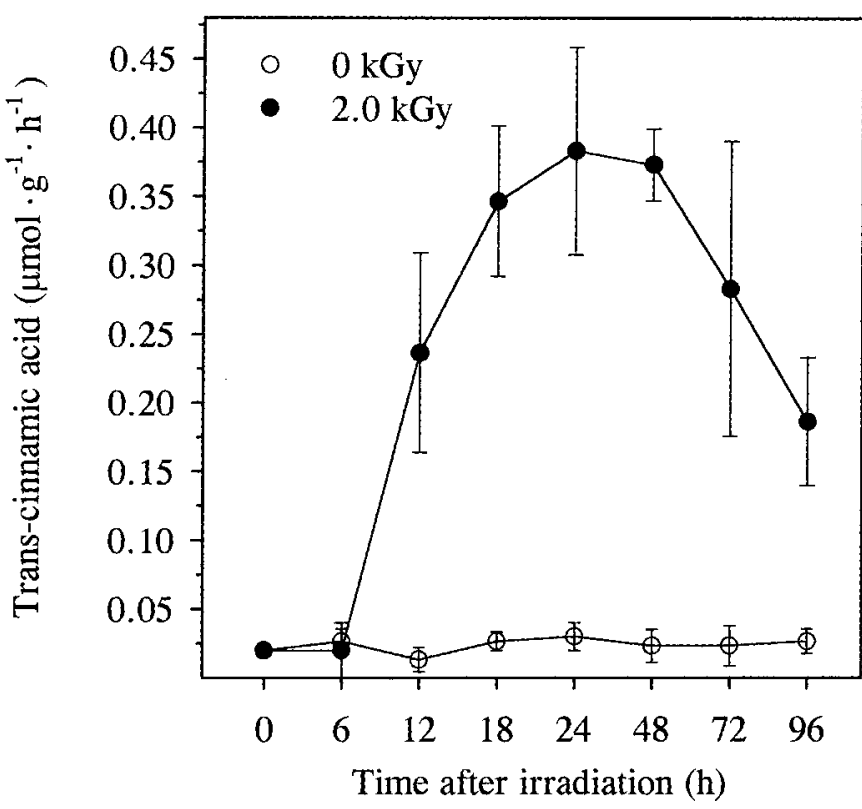

Fig. 1. Changes in phenylalanine ammonia-lyase activity in grapefruit flavedo after exposure to $2.0 \mathrm{kGy}$ irradiation. Vertical bars represent SE values of three replications. Experimental conditions are described in the text. Values are expressed on a dry weight basis.

for $2 \mathrm{~h}$. The suspension was centrifuged again and the supernatant saved. The polymeric thioglycolic acid derivatives were then precipitated by $200 \mathrm{~mL} 12 \mathrm{~mol} \cdot \mathrm{L}^{-1} \mathrm{HCl}$ over an ice bath for $2 \mathrm{~h}$. After centrifugation, the pellet was dissolved in $1 \mathrm{~mL} 0.5 \mathrm{~mol} \cdot \mathrm{L}^{-1}$ $\mathrm{NaOH}$ and the absorbance read at $295 \mathrm{~nm}$. To determine coumarins, the filtrate from the chloroform homogenization was concentrated on a rotary evaporator (Rotavapor ER120, Buchi, Fawil, Switzerland) and dissolved in $10 \mathrm{~mL}$ chloroform and the absorbance read at $320 \mathrm{~nm}$.

LIPIDS. Steryl lipids were extracted from lyophilized tissue and fractioned into free sterols (FSs), steryl esters (SEs), acylated steryl glycosides (ASGs), and steryl glycosides (SGs), and the major sterols determined in each steryl lipid fraction as described previously (McDonald et al., 1998).

Statistical analysis. For the time-course experiment, the completely randomized experimental design was replicated three times. The main effect of irradiation $(0.0$ or $2.0 \mathrm{kGy}$ ) was analyzed over time with analysis of variance (ANOVA) procedures (SAS Inst., Inc., Cary, N.C.). For the effects of grapefruit canopy position, heat treatments, and irradiation on peel pitting and biochemical changes in flavedo, the completely randomized experimental design was replicated on the three harvest dates. The $2 \times 2 \times 3$ factorial with canopy position (exterior or interior), irradiation level $(0.0$ or $1.0 \mathrm{kGy})$ and heat treatment $(20,38$ or 42 ${ }^{\circ} \mathrm{C}$ ), as main effects was analyzed with ANOVA procedures. Unless noted otherwise, only results significant at $P \leq 0.05$ are discussed.

\section{Results}

RADIATION-INDUCED BIOCHEMICAL CHANGES OVER TIME. The $2.0 \mathrm{kGy}$ radiation-induced a transient increase in PAL activity (Fig. 1).PAL activity increased $\approx 18$-fold $24 \mathrm{~h}$ after irradiation and then decreased. Irradiation did not affect the levels of phenols, flavanols, coumarins, or lignins in the initial $96 \mathrm{~h}$ following irradiation. Stigmasterol levels increased progressively in the four steryl lipid fractions following irradiation (Table 1). Stigmasterol increased in the FS and SG fractions at 72 and $96 \mathrm{~h}$ and in the ASG fraction at $96 \mathrm{~h}$. Irradiation did not induce any other changes in sterols in steryl lipids with the exception of decreases in isofucosterol levels in the FS fraction at 72 and $96 \mathrm{~h}$ and the SG fraction at 24 and $96 \mathrm{~h}$ (data not presented).

Peel PitTing AND PhenYlPRopanoId METABolism. There was more peel pitting in exterior canopy fruit $(26.6 \%)$ than in interior canopy fruit (14.6\%) (Table 2). PAL activity in fruit flavedo was not influenced by canopy position. Levels of phenols, flavanols, and coumarins were higher in exterior than in interior canopy fruit. Lignin levels were not affected by canopy position.

Thirty-eight percent of irradiated fruit were pitted. Irradiation also induced a 7.5-fold increase in PAL activity, but no change in phenolic compounds. Pitting and PAL activity were reduced by the $38{ }^{\circ} \mathrm{C}$ heat treatment and further by the $42{ }^{\circ} \mathrm{C}$ treatment. Coumarin levels were reduced similarly by the heat treatments, but the other phenolic compounds were not affected.

There was an interaction between canopy position and irradiation dose effects for coumarins. Increasing the temperature of heat treatment of irradiated fruit reduced coumarin levels whereas coumarin levels of nonirradiated fruit were highest with the $38^{\circ} \mathrm{C}$ heat treatment. There was an interaction between irradiation dose and temperature for PAL activity. Increasing the temperature of the heat treatment of irradiated fruit reduced PAL activity whereas PAL activity of nonirradiated fruit was highest with the $38^{\circ} \mathrm{C}$ heat treatment.

STERYL LIPIDS. Cholesterol, campesterol, stigmasterol, $\beta$-sitosterol, and isofucosterol were the major sterols in all steryl lipid fractions in grapefruit peel flavedo with the exception that cholesterol was not detected in the SG fraction (Table 3). Generally, individual sterols were higher in the four steryl lipid fractions in

Table 1. Effect of irradiation on stigmasterol levels $\mathrm{s}^{\mathrm{z}}$ in steryl lipids in grapefruit flavedo. Each value is the mean of three replications.

\begin{tabular}{|c|c|c|c|c|c|c|c|c|}
\hline \multirow{2}{*}{$\begin{array}{l}\text { Time after } \\
\text { irradiation } \\
\text { (h) }\end{array}$} & \multicolumn{2}{|c|}{$\begin{array}{l}\text { Free } \\
\text { sterol }\end{array}$} & \multicolumn{2}{|c|}{$\begin{array}{l}\text { Steryl } \\
\text { ester }\end{array}$} & \multicolumn{2}{|c|}{$\begin{array}{c}\text { Steryl } \\
\text { glycoside }\end{array}$} & \multicolumn{2}{|c|}{$\begin{array}{c}\text { Acylated } \\
\text { steryl glycoside }\end{array}$} \\
\hline & $0.0 \mathrm{kGy}$ & $2.0 \mathrm{kGy}$ & $0.0 \mathrm{kGy}$ & $2.0 \mathrm{kGy}$ & $0.0 \mathrm{kGy}$ & $2.0 \mathrm{kGy}$ & $0.0 \mathrm{kGy}$ & $2.0 \mathrm{kGy}$ \\
\hline 6 & 49.7 & 55.9 & 27.2 & 31.8 & 1.5 & 1.7 & 1.7 & 1.3 \\
\hline 12 & 50.6 & 59.7 & 32.3 & 27.4 & 1.1 & 1.6 & 1.5 & 1.9 \\
\hline 18 & 45.5 & 50.0 & 27.2 & 29.7 & 1.3 & 1.6 & 1.7 & 1.7 \\
\hline 24 & 59.3 & 55.3 & 27.0 & 30.2 & 1.3 & 1.6 & 1.7 & 1.9 \\
\hline 48 & 64.7 & 80.9 & 28.5 & 32.5 & 1.5 & 2.2 & 2.3 & 2.7 \\
\hline 72 & 55.3 & $108.0^{*}$ & 36.3 & 42.9 & 1.6 & $3.5^{* * *}$ & 1.9 & 3.3 \\
\hline 96 & 51.9 & $100.0^{*}$ & 39.3 & 44.6 & 1.6 & $3.6^{*}$ & 1.5 & $3.8^{*}$ \\
\hline
\end{tabular}

${ }^{\mathrm{z}}$ Determined $24 \mathrm{~h}$ following $2.0 \mathrm{kGy}$ irradiation and expressed as $\mathrm{mg} \cdot \mathrm{g}^{-1}$ dry weight.

${ }^{*}, * *$ Significant at $P \leq 0.05$ or 0.01 , respectively, across irradiation levels. 
Table 2. Effects of grapefruit canopy position, irradiation, and heat treatments on peel pitting ${ }^{\mathrm{z}}$ and $^{\text {phenylpropanoid metabolism }}{ }^{\mathrm{y}}$ in flavedo.

\begin{tabular}{|c|c|c|c|c|c|c|}
\hline Treatment & $\begin{array}{c}\text { Pitting } \\
(\%)\end{array}$ & $\begin{array}{c}\text { PAL } \\
(\mu \mathrm{mol} \text { trans } \\
\text { cinnamic acid })\end{array}$ & $\begin{array}{c}\text { Phenols } \\
\text { (absorbance } \\
\text { at } 725 \mathrm{~nm} \text { ) }\end{array}$ & $\begin{array}{l}\text { Flavanols } \\
\text { (absorbance } \\
\text { at } 500 \mathrm{~nm} \text { ) }\end{array}$ & $\begin{array}{l}\text { Coumarins } \\
\text { (absorbance } \\
\text { at } 320 \mathrm{~nm} \text { ) }\end{array}$ & $\begin{array}{c}\text { Lignins } \\
\text { (absorbance } \\
\text { at } 295 \mathrm{~nm} \text { ) }\end{array}$ \\
\hline \multicolumn{7}{|l|}{ Canopy position } \\
\hline Interior & 14.6 & 0.09 & 0.228 & 0.138 & 0.348 & 0.309 \\
\hline \multicolumn{7}{|l|}{ Dose (kGy) } \\
\hline \multicolumn{7}{|l|}{ Temp $\left({ }^{\circ} \mathrm{C}\right)$} \\
\hline 20 & 25.8 & 0.13 & 0.291 & 0.179 & 0.397 & 0.302 \\
\hline 38 & 19.1 & 0.08 & 0.286 & 0.169 & 0.362 & 0.316 \\
\hline 42 & 16.7 & 0.05 & 0.288 & 0.170 & 0.358 & 0.304 \\
\hline \multicolumn{7}{|c|}{ Significance of main factors and interactions } \\
\hline $\mathrm{C} \times \mathrm{D}$ & NS & NS & NS & NS & * & NS \\
\hline $\mathrm{C} \times \mathrm{T}$ & NS & NS & NS & NS & NS & NS \\
\hline $\mathrm{D} \times \mathrm{T}$ & NS & $*$ & NS & NS & NS & NS \\
\hline
\end{tabular}

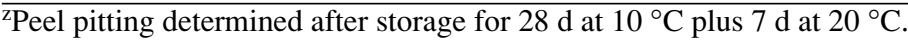

yPAL activity and phenolic compounds determined $24 \mathrm{~h}$ following $1.0 \mathrm{kGy}$ irradiation.

Ns, ${ }^{*}, * *, * * *$ Nonsignificant or significant at $P \leq 0.05,0.01$, or 0.001 , respectively.

exterior canopy fruit compared with interior canopy fruit. There was more cholesterol in the FS fraction in exterior canopy fruit compared with fruit from the interior canopy. There was more $\beta$ sitosterol in FS, SE, and SG fractions from exterior canopy fruit than in interior canopy fruit. Isofucosterol levels were higher in the FS fraction of interior canopy fruit. Campesterol levels were higher in SE and SG fractions of exterior canopy fruit. Stigmasterol levels were higher in the SE fraction of exterior canopy fruit.
Irradiation increased campesterol in the FS and SG fractions and decreased isofucosterol in the FS fraction. Heat treatments had no effect on individual sterol levels.

There were two-way interactions between canopy position and irradiation dose for campesterol, stigmasterol, and $\beta$-sitosterol in the SE fraction and $\beta$-sitosterol in the ASG fraction (Table 3). There were two-way interactions between heat treatment temperature and irradiation dose for cholesterol, campesterol,

Table 3. Effects of grapefruit tree canopy position, irradiation, and heat treatments on steryl lipids ${ }^{\mathrm{z}, \mathrm{y}}$ in flavedo. Values are expressed on a dry weight basis.

\begin{tabular}{|c|c|c|c|c|c|c|c|c|c|c|c|c|c|c|c|c|c|c|c|c|}
\hline \multirow[b]{2}{*}{ Treatment } & \multicolumn{5}{|c|}{$\begin{array}{l}\text { Free sterols } \\
\quad\left(\mu \mathrm{g} \cdot \mathrm{g}^{-1}\right)\end{array}$} & \multicolumn{5}{|c|}{$\begin{array}{l}\text { Steryl esters } \\
\left(\mu \mathrm{g} \cdot \mathrm{g}^{-1}\right)\end{array}$} & \multicolumn{5}{|c|}{$\begin{array}{l}\text { Steryl glycosides } \\
\quad\left(\mu \mathrm{g} \cdot \mathrm{g}^{-1}\right)\end{array}$} & \multicolumn{5}{|c|}{$\begin{array}{l}\text { Acylated steryl glycosides } \\
\qquad\left(\mu \mathrm{g} \cdot \mathrm{g}^{-1}\right)\end{array}$} \\
\hline & Chol & Cam & Stig & Bsit & Isof & Chol & Cam & Stig & Bsit & Isof & Chol & Cam & Stig & Bsit & Isof & Chol & Cam & Stig & Bsit & Isof \\
\hline \multicolumn{21}{|l|}{ Canopy position } \\
\hline Exterior & 3.38 & 33.1 & 49.1 & 264 & 12.2 & 20.5 & 52.0 & 29.5 & 732 & 110 & --- & 4.06 & 3.22 & 51.2 & 11.1 & 14.1 & 2.08 & 1.97 & 32.3 & 6.68 \\
\hline Interior & 2.74 & 30.2 & 49.5 & 226 & 15.1 & 22.2 & 43.2 & 26.8 & 511 & 147 & --- & 3.32 & 2.82 & 40.1 & 9.3 & 13.2 & 2.05 & 2.26 & 30.1 & 6.14 \\
\hline \multicolumn{21}{|l|}{ Dose (kGy) } \\
\hline 0.0 & 2.88 & 29.6 & 47.6 & 241 & 15.5 & 21.9 & 48.4 & 27.4 & 615 & 129 & --- & 3.14 & 2.83 & 43.6 & 10.4 & 13.4 & 1.97 & 2.18 & 32.5 & 6.61 \\
\hline 1.0 & 3.28 & 34.0 & 51.1 & 250 & 11.6 & 20.8 & 46.8 & 28.9 & 629 & 128 & --- & 4.24 & 3.21 & 47.6 & 10.0 & 13.9 & 2.16 & 2.05 & 29.7 & 6.21 \\
\hline \multicolumn{21}{|l|}{ Temp $\left({ }^{\circ} \mathrm{C}\right)$} \\
\hline 20 & 2.94 & 30.8 & 48.1 & 233 & 12.5 & 21.4 & 47.4 & 27.4 & 590 & 120 & --- & 3.94 & 3.29 & 49.1 & 11.1 & 12.1 & 2.12 & 2.37 & 31.4 & 6.64 \\
\hline 38 & 3.32 & 32.8 & 51.9 & 260 & 13.7 & 21.9 & 46.2 & 27.3 & 619 & 122 & --- & 3.73 & 3.13 & 46.1 & 10.2 & 13.6 & 2.03 & 1.95 & 30.7 & 5.95 \\
\hline 42 & 2.94 & 31.5 & 48.0 & 243 & 14.7 & 20.7 & 49.2 & 29.6 & 652 & 143 & --- & 3.40 & 2.64 & 41.6 & 9.3 & 15.2 & 2.04 & 2.05 & 31.3 & 6.64 \\
\hline \multicolumn{21}{|c|}{ Significance of main factors and interactions } \\
\hline Canopy position (C) & * & NS & NS & $*$ & $*$ & NS & $* * *$ & $*$ & $* * *$ & NS & & $*$ & NS & $* *$ & NS & NS & NS & NS & NS & NS \\
\hline Dose (D) & NS & $* *$ & NS & NS & $* * *$ & NS & NS & NS & NS & NS & & $* *$ & NS & NS & NS & NS & NS & NS & NS & NS \\
\hline Temp (T) & NS & NS & NS & NS & NS & NS & NS & NS & NS & NS & & NS & NS & NS & NS & NS & NS & NS & NS & NS \\
\hline$C \times D$ & NS & NS & NS & NS & NS & NS & $* *$ & $*$ & $* *$ & NS & & NS & NS & NS & NS & NS & NS & NS & $*$ & NS \\
\hline $\mathrm{C} \times \mathrm{T}$ & NS & NS & NS & NS & NS & NS & NS & NS & NS & NS & & NS & NS & NS & NS & NS & NS & NS & NS & NS \\
\hline $\mathrm{D} \times \mathrm{T}$ & * & * & NS & NS & $* *$ & NS & $*$ & * & * & NS & & NS & NS & NS & NS & NS & NS & NS & NS & NS \\
\hline
\end{tabular}

${ }^{\mathrm{z}}$ Determined $24 \mathrm{~h}$ following $1.0 \mathrm{kGy}$ irradiation.

yFive sterols were quantified: cholesterol (Chol), campesterol (Cam), stigmasterol (Stig), $\beta$-sitosterol (Bsit), and isofucosterol (Isof).

Ns,*,**,**** Nonsignificant or significant at $P \leq 0.05,0.01$, or 0.001 , respectively. 
and isofucosterol in the FS fraction and campesterol, stigmasterol, and $\beta$-sitosterol in the SE fraction.

\section{Discussion}

Grapefruit flavedo is much more sensitive to abiotic stresses than pulp and peel damage (pitting) that develops frequently. Grapefruit from the sun-exposed exterior canopy are much more susceptible to CI (McDonald et al., 1993; Purvis, 1980) than those from the shaded interior canopy. Peel pitting caused by $\mathrm{CI}$ is indistinguishable from that caused by irradiation. This study is the first report of exterior canopy grapefruit being more sensitive to irradiation-induced injury compared with interior canopy fruit (Table 2).

The development of chilling injury symptoms on exterior canopy grapefruit is related to epicuticular wax morphology and composition (McDonald et al., 1993). Four major triterpenols are greater in exterior canopy fruit, while six triterpenones show the reverse trend (Nordby and McDonald, 1995). The present study shows that exterior canopy fruit flavedo had higher levels of total phenols, flavanols, and coumarins in spite of the fact that PAL activity was similar to interior canopy fruit flavedo (Table 2).

In this study, an oxidative stress condition was induced in grapefruit flavedo through application of a gamma irradiation dose (Riov, 1975). Development of necrotic lesions in the flavedo tissue was preceded by transient induction of PAL $24 \mathrm{~h}$ after irradiation. Change in phenylpropanoid metabolism is an important response to stress. PAL has been shown to be the rate controlling enzyme in phenolic synthesis and wounding of citrus (Citrus paradisi Macf. 'Marsh'; Citrus sinensis L. Osbeck 'Shamouti') (Riov et al., 1968) and lettuce (Lactuca sativa L.) (Ke and Saltveit, 1989). Presumably, stress-mediated tissue browning is induced by increased PAL activity and compromised membrane integrity which disrupts cellular compartmentalization and allows polyphenol oxidase to come into contact with the phenolics produced following the increased PAL activity (Peiser et al., 1998).

Several reports have documented accumulation of phenolic compounds in plant tissues following irradiation (Dubery, 1992). It seems that increased phenolic biosynthesis is a typical response of plant tissues to irradiation, reflecting a stress condition. However, we found no accumulation of phenolic compounds after the peak of PAL activity had been attained (Table 2). Riov et al. (1968) showed that levels of phenolic compounds following irradiation depend on grapefruit maturity. Therefore, accumulation of phenolic compounds in irradiated grapefruit may be more dependent upon fruit maturity than other factors. Additionally, an increase in PAL activity has not always been correlated with production of specific phenylpropanoid compounds (Jones, 1984). This may be due to removal of phenols by some mechanism like oxidation of phenols to quinones, which are not reactive to the assay for phenolic compounds (Swain and Hillis, 1959). Similar results were obtained for irradiated mango (Mangifera indica L.) fruit (Frylinck et al., 1987). In the present study, PAL activity of nonirradiated flavedo tissue remained low (Fig. 1).

Preirradiation heat treatment resulted in two different phenomena: 1) it diminished irradiation-induced increases in PAL activity, and 2) inhibited development of irradiation-induced pitting of flavedo. A heat shock given before chilling of mandarins (Citrus reticulata Blanco.) overrides chilling-induced PAL activity and pitting (Martinez-Tellez and Lafuente, 1997). An ethylene-induced increase in PAL activity is not a prerequisite for development of russet spotting lesions in lettuce, though the brown discoloration of the cells does require PAL activity (Ke and Saltveit, 1989). In the present study, it is not clear whether the irradiation-induced increase in PAL activity caused peel pitting, or was involved in the resulting brown discoloration of cells.

The most prominent change in lipid composition during the 96 $\mathrm{h}$ following irradiation was the increase in stigmasterol in the FS, SG, and ASG steryl lipid fractions (Table 1). Although $\beta$ sitosterol levels did not change appreciably in these fractions (data not presented), the stigmasterol to $\beta$-sitosterol ratio increase during the $96 \mathrm{~h}$ following irradiation averaged 2.5, paralleling changes seen in ripening tomato (Lycopersicon esculentum Mill.) fruit (McDonald et al., 1998). There were stigmasterol increases in the FS, SG, and ASG fractions in irradiated fruit compared with nonirradiated grapefruit. The increase in the proportion of stigmasterol in irradiated fruit could result from decreased rates of glycosylation and esterification or from increased rates of deglycosylation and deesterification (Whitaker, 1993). These changes in steryl lipids could be a direct result of the irradiation process.

Canopy position influenced individual sterol levels in all four steryl lipid fractions, with differences being significant in the FS, SE, and SG fractions (Table 3). On a dry weight (DW) basis, there were $10 \%, 20 \%, 20 \%$, and $6 \%$ more total sterols in the FS, SE, SG, and ASG fractions, respectively, in exterior versus interior canopy fruit. Although there are limited reports of compositional differences between exterior and interior canopy grapefruit (McDonald et al., 1993; Nordby and McDonald, 1995; Purvis, 1980), it is apparent that canopy position exerts a very strong influence on the biochemical makeup of flavedo. Aside from minimal steryl lipid differences between irradiated and nonirradiated fruit, there were no differences when making comparisons between heated and nonheated fruit (Table 3). Apparently, irradiation levels and heat treatments used in this study had a minimal effect on the resulting steryl lipid profiles in grapefruit flavedo.

In conclusion, our data indicate that exterior canopy grapefruit are more sensitive to irradiation damage in the form of peel pitting than interior canopy fruit. A transient increase in PAL activity was induced by irradiation, and was correlated with fruit peel pitting. The reduction of pitting induced by heat treatments may involve PAL activity. Likewise, our results could be interpreted that heat treatment initiated some defense mechanism against irradiation such as formation of heat shock proteins and, therefore, the irradiation-induced increase in PAL was not required in heat-treated grapefruit to cope with stress.

\section{Literature Cited}

Buttery, R.G. and L.C. Ling. 1993. Volatile components of tomato fruit and plant parts, relationship and biogenesis, p. 22-34. In: R. Teranishi, R.G. Buttery, and H. Sugisawa (eds.). Bioactive volatile compounds from plants. Amer. Chem. Soc. Symp. Ser. No. 525. Amer. Chem. Soc., Wash., D.C.

Dubery, I.A. 1992. Elicitation of enhanced phenylpropanoid metabolism in citrus flavedo by gamma-irradiation. Phytochemistry 31:26592662.

El-Kazzaz, M.K., A. Chordas, and A.A. Kader. 1983. Physiological and compositional changes in orange fruit in relation to modification of their susceptibility to Penicillium italicum by ethylene treatments. J. Amer. Soc. Hort. Sci. 108:618-621.

Ferullo, J.M., L. Nespoulous, and C. Triantaphylides. 1994. Gamma-ray induced changes in the synthesis of tomato pericarp protein. Plant Cell Environ. 17:901-911.

Frylinck, L., I.A. Dubery, and J.C. Schabort. 1987. Biochemical changes 
involved in stress response and ripening behavior of $\gamma$-irradiated mango fruit. Phytochemistry 26:681-686.

Gholap, A.S., C. Bandyopadhyay, and P.M. Nair. 1990. Lipid composition and flavor changes in irradiated mango (var. Alphonso). J. Food Sci. 55:1579-1584.

Graham, M.Y. and T.L. Graham. 1991. Rapid accumulation of anionic peroxidases and phenolic polymers in soybean cotyledon tissues following treatment with Phythophthora megasperma f. sp. Glycinea wall gluten. Plant Physiol. 97:1445-1455.

Hatton, T.T. and R.H. Cubbedge. 1983. Preferred temperature for prestorage conditioning of 'Marsh' grapefruit to prevent chilling injury at low temperature. HortScience 18:721-722.

Hatton, T.T., R.H. Cubbedge, L.A. Risse, P.W. Hale, D.H. Spalding, D. von Windeguth, and V. Chew. 1984. Phytotoxic responses of Florida grapefruit to low-dose irradiation. J. Amer. Soc. Hort. Sci. 109:607610.

Ismail, M. and G.E. Brown. 1979. Postharvest wound healing in citrus fruit: Induction of phenylalanine ammonia-lyase in injured 'Valencia' orange flavedo. J. Amer. Soc. Hort. Sci. 104:126-129.

Jones, D.H. 1984. Phenylalanine ammonia-lyase: Regulation of its induction, and its role in plant development. Phytochemistry 23:13491359.

Ke, D. and M.E. Saltveit, Jr. 1989. Wound-induced ethylene production, phenolic metabolism and susceptibility to russet spotting in iceberg lettuce. Physiol. Plant. 76:412-418.

Klein, J.D. and S. Lurie. 1992. Heat treatments for improved postharvest quality of horticultural crops. HortTechnology 2:316-320.

Lester, G.E. and B.D. Whitaker. 1996. Gamma-ray-induced changes in hypodermal mesocarp tissue plasma membrane of pre- and poststorage muskmelon. Physiol. Plant. 98:265-270.

Lester, G.E. and D.A. Wolfenbarger. 1990. Comparisons of cobalt-60 gamma irradiation dose rates on grapefruit flavedo tissue and on Mexican fruit-fly mortality. J. Food Protection 53:329-331.

Martinez-Tellez, M.A. and M.T. Lafuente. 1997. Effect of high temperature conditioning on ethylene, phenylalanine ammonia-lyase, peroxidase and polyphenol oxidase activities in flavedo of chilled 'Fortune' mandarin fruit. J. Plant Physiol. 150:674-678.

McDonald, R.E., T.G. McCollum, and E.A. Baldwin. 1998. Heat treatment of mature-green tomatoes: Differential effects of ethylene and partial ripening. J. Amer. Soc. Hort. Sci. 123:457-462.

McDonald, R.E., H.E. Nordby, and T.G. McCollum. 1993. Epicuticular wax morphology and composition are related to grapefruit chilling injury. HortScience 28:311-312.

Miller, W.R. and R.E. McDonald. 1996. Postharvest quality of GAtreated Florida grapefruit after gamma irradiation with TBZ and storage. Postharvest Biol. Technol. 7:253-260.

Miller, W.R. and R.E. McDonald. 1998. Amelioration of irradiation injury to Florida grapefruit by pretreatment with vapor heat or fungicides. HortScience 33:100-102.

Mudd, J.B. and T.T. McManus. 1980. Effect of steryl glycosides on the phase transition of dipalmitoyl lecithin. Plant Physiol. 65:78-80.

Nordby, H.E. and R.E. McDonald. 1995. Variations in chilling injury and epicuticular wax composition of white grapefruit with canopy position and fruit development during the season. J. Agr. Food Chem. 43:1828-1833.

Paull, R.E. and R.E. McDonald. 1994. Heat and cold treatments, p. 191222. In: R.E. Paull and J.W. Armstrong (eds.). Insect pests and fresh horticultural products: Treatments and responses. CAB Intl., Wallingford, U.K.

Peiser, G., G. Lopez-Galvez, M. Cantwell, and M.E. Saltveit. 1998. Phenylalanine ammonia lyase inhibitors control browning of cut lettuce. Postharvest Biol. Technol. 14:171-177.

Peterson, G.L. 1977. A simplification of the protein method of Lowry et al. which is generally more applicable. Anal. Biochem. 83:346-356.

Purvis, A.C. 1980. Influence of canopy depth on susceptibility of 'Marsh' grapefruit to chilling injury. HortScience 15:731-733.

Riov, J. 1975. Histochemical evidence for the relationship between peel damage and the accumulation of phenolic compounds in gammairradiated citrus fruit. Radiation Bot. 15:257-260.

Riov, J. and R. Goren. 1970. Effect of gamma radiation and ethylene on protein synthesis in peel of mature grapefruit. Radiation Bot. 10:155160.

Riov, J., S.P. Monselise, and R.S. Kahan. 1968. Effect of gamma irradiation on phenylalanine ammonia-lyase activity and accumulation of phenolic compounds in citrus fruit peel. Radiation Bot. 8:463-466.

Riov, J., S.P. Monselise, and R.S. Kahan. 1969. Ethylene induction of phenylalanine ammonia-lyase activity in citrus fruit peel. Plant Physiol. 44:631-635.

Romani, R.J. 1966. Biochemical responses of plant systems to large doses of ionizing radiation. Radiation Bot. 6:87-104.

Simpson, S.E. 1993. Caribbean fruit fly-free zone certification protocol in Florida (Diptera:Tephritidae). Florida Entomol. 76:228-233.

Swain, T. and W.E. Hillis. 1959. The phenolic constituents of Prunus domestica I.-The quantitative analysis of phenolic constituents. J. Sci. Food Agr. 10:63-68.

U.S. Department of Agriculture. 1968. U.S. standards for grades of Florida grapefruit, USDA Agr. Mktg. Serv., Wash., D.C.

U.S. Department of Agriculture. 1996. The application of irradiation to phytosanitary problems. Animal and Plant Health Plant Inspection Service Docket No. 95-008-1. Fed. Reg. 61(95):24433-24439.

U.S. Government Printing Office. 1966. Fed. Reg. 56(75):13375-13399. von Windeguth, D. 1982. Effects of gamma irradiation on the mortality of Caribbean fruit fly in grapefruit. Proc. Fla. State Hort. Soc. 95:235237.

Whitaker, B.D. 1993. Lipid changes in microsomes and crude plastid fractions during storage of tomato fruits at chilling and nonchilling temperatures. Phytochemistry 32:265-271.

Zucker, M. 1968. Sequential induction of phenylalanine ammonia-lyase and a lyase-inactivating system in potato tuber disks. Plant Physiol. 43:365-374. 